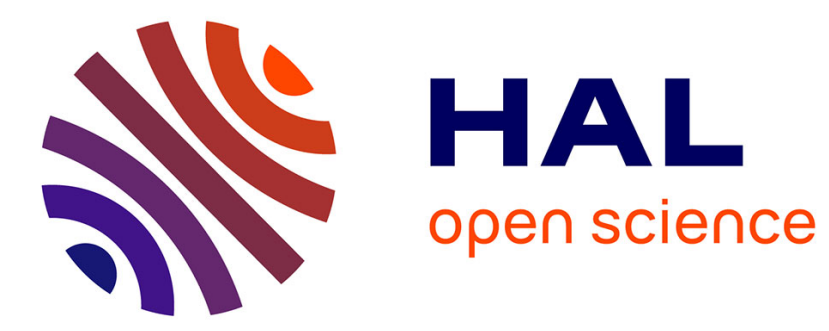

\title{
Electron spin and cyclotron resonance of laser annealed silicon
}

\author{
A. Goltzené, J.C. Muller, C. Schwab, P. Siffert
}

\section{To cite this version:}

A. Goltzené, J.C. Muller, C. Schwab, P. Siffert. Electron spin and cyclotron resonance of laser annealed silicon. Revue de Physique Appliquée, 1980, 15 (1), pp.21-23. 10.1051/rphysap:0198000150102100 . jpa-00244693

\section{HAL Id: jpa-00244693 https://hal.science/jpa-00244693}

Submitted on 1 Jan 1980

HAL is a multi-disciplinary open access archive for the deposit and dissemination of scientific research documents, whether they are published or not. The documents may come from teaching and research institutions in France or abroad, or from public or private research centers.
L'archive ouverte pluridisciplinaire HAL, est destinée au dépôt et à la diffusion de documents scientifiques de niveau recherche, publiés ou non, émanant des établissements d'enseignement et de recherche français ou étrangers, des laboratoires publics ou privés. 


\title{
Electron spin and cyclotron resonance of laser annealed silicon (*)
}

\author{
A. Goltzené $(* *)$, J. C. Muller $(* * *)$, C. Schwab $(* *)$, P. Siffert $(* * *)$ \\ (**) Laboratoire de Spectroscopie et d'Optique du Corps Solide, \\ Associé au C.N.R.S. no 232 , Université Louis-Pasteur, 5, rue de l'Université, 67000 Strasbourg, France \\ $\left({ }^{* * *}\right)$ Centre de Recherches Nucléaires, Groupe de Physique et Applications des Semiconducteurs (PHASE), \\ 67037 Strasbourg Cedex, France
}

\begin{abstract}
Résumé. - Les mesures de RPE et de résonance cyclotron ont montré que le recuit laser de Si est corrélé à l'apparition de signaux attribués au défaut $\left[\mathrm{V}+\mathrm{O}_{\mathrm{i}}\right]^{-}$dans le matériau non dopé, et à une forte diminution du signal RPE du donneur dans Si implanté P.
\end{abstract}

Abstract. - EPR and cyclotron resonance investigations have been performed on laser annealed Si wafers, leading to the identification of the $\left[\mathrm{V}+\mathrm{O}_{\mathrm{i}}\right]^{-}$complex in virgin $\mathrm{Si}$ and to a donor signal quenching in P-implanted Si.

Introduction. - Laser annealing techniques have been investigated recently for improving various semiconducting devices such as integrated circuits and solar cells.

Initial studies have shown that the restoring mechanism of the damaged surface layers or of amorphous deposits on top of the single crystalline silicon substrate will depend on the lasing mode. CW illumination is believed to initiate a solid phase epitaxial process, whereas the pulsed mode induces a liquid epitaxial regrowth as soon as the power density exceeds some threshold, lying close to $1 \mathrm{~J} / \mathrm{cm}^{2}$ [1].

To our knowledge, no direct determination of the residual defects which remain in these restored layers have been tempted, although some deep levels have already been identified by sensitive electrical transport measurement such as DLTS [2] or TSC [3].

Therefore the aim of this work was to investigate these defects by electron paramagnetic resonance (EPR), which is a very specific technique. In some instances, it will also allow to record cyclotron resonance (CR) data simultaneously.

Experimental. - EPR and CR have been performed on high purity and on phosphorus implanted silicon.

The high purity silicon was float zone material of n-type, with a high resistivity of $10^{4} \Omega \mathrm{cm}$. The concentrations of the residual impurities were as follows : $O \sim 10^{16} \mathrm{~cm}^{-3}, B$ and $P \sim 10^{12} \mathrm{~cm}^{-3}$; wafer orientation was [110].

(*) Conférence présentée au Congrès de la Société Française de Physique (Toulouse, 25-30 juin 1979).
The implanted material was of low resistivity $(160 \Omega \mathrm{cm})$ and of initial p-type ( $B$ doped). Doses of $5 \times 10^{16}$ to $10^{17} \mathrm{~cm}^{-2} \mathrm{P}^{31}$ ions were implanted at $10-15 \mathrm{keV}$ on each side of [111] oriented wafers. The expected penetration depth at these energies is about $50 \mathrm{~nm}$.

The anneals were performed in air with a $Q$-switched ruby laser $(\lambda=694.3 \mathrm{~nm})$ with a pulse duration of $25 \mathrm{~ns}$ at half power. The power density was $2.7 \mathrm{~J} \mathrm{~cm}^{-2}$ for the virgin silicon to be well above the melting temperature and up to 10 successive shots have been employed. For the implanted silicon, the laser energy was set just up to the threshold energy ( $\sim 1.1 \mathrm{~J} \mathrm{~cm}^{-2}$ ). After this operation, samples of $3 \times 4 \times 1 \mathrm{~mm}^{3}$ were cut out from the $6 \mathrm{~mm}$ diameter spots in order to insure a good homogeneity.

EPR and CR measurements were done at $4.2 \mathrm{~K}$ and $9.3 \mathrm{GHz}$ on stacks made of 2 or 3 samples to enhance the lowest signals.

Results. - The virgin silicon samples are EPR signal free. After the laser anneal, an isotropic line appears with a Landé factor $g_{1}=2.0055 \pm 0.0005$. After etching off the surface layer, or after a thermal anneal at $500^{\circ} \mathrm{C}$ for $30 \mathrm{~min}$, this signal disappears again. Maximum signal intensity corresponds to some $10^{13}$ spins.

A light irradiation is needed to observe a CR signal (Fig. 2). It is performed using an unfiltered $55 \mathrm{~W}$ quartz iodine lamp, illuminating the sample within the cavity through an optical port. After the laser anneal only slight variations are observed : the hole CR linewidth decreases, whereas the electron 


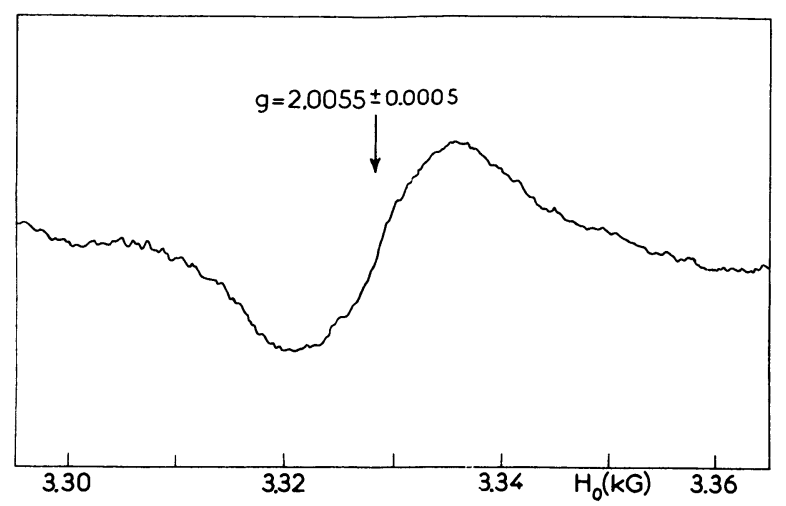

Fig. 1. - EPR of $10^{4} \Omega \mathrm{cm} n$-type $\mathrm{Si}$, after laser annealing.

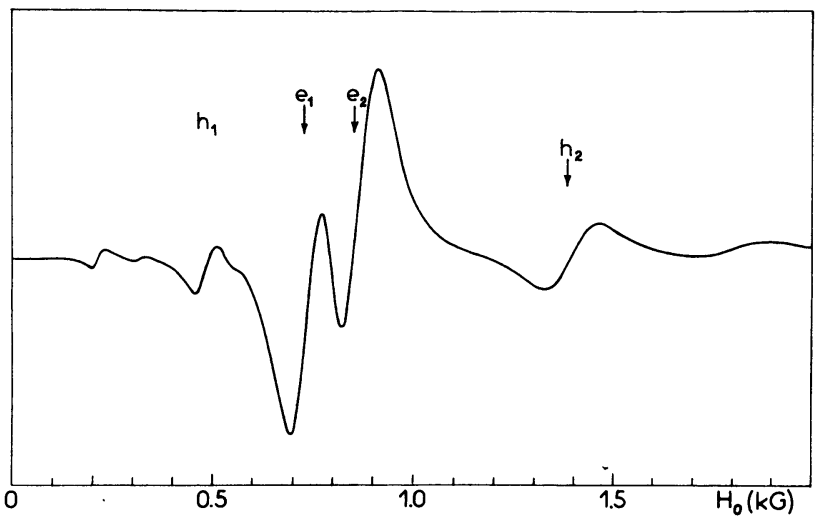

Fig. 2. - Cyclotron resonance (CR) of $10^{4} \Omega \mathrm{cm} n$-type $\mathrm{Si}$, for $H_{0}$ slightly off a (110) direction. Intensity and linewidth are measured for the electron CR $\left(e_{1} e_{2}\right)$ and the heavy hole CR $\left(h_{2}\right)$.

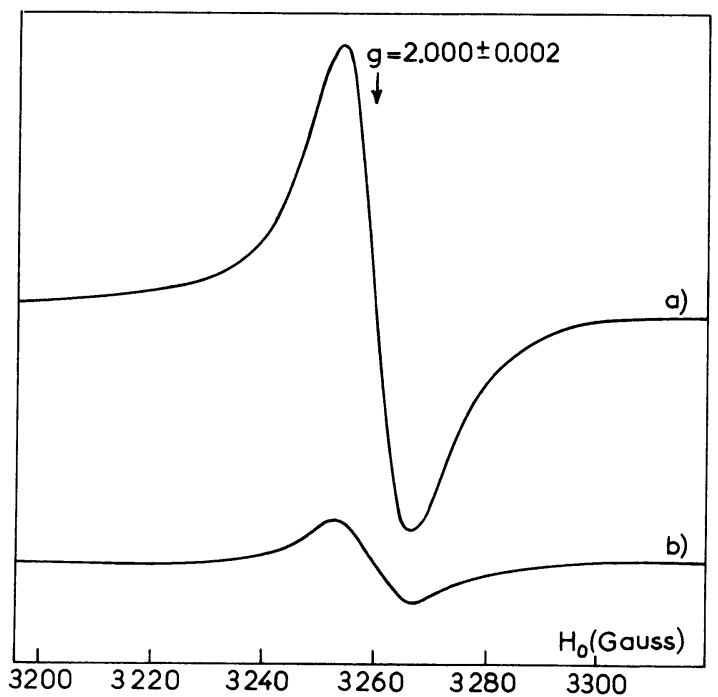

Fig. 3. - EPR of P-implanted Si, before $(a)$ and after $(b)$ laser annealing.

CR linewidth increases, but both their intensities decrease.

For the implanted $\mathrm{Si}$, an isotropic EPR line appears at $g_{2}=2.000 \pm 0.002$ (Fig. 3). Before annealing, the spin number corresponds to some $10^{14} \mathrm{~cm}^{-3}$.
After the laser shots, the intensity of this line decreases approximately by one order of magnitude.

Preliminary measurements of CR in these samples have shown a more complex behaviour, needing further investigations.

Discussion. - To the defect signed by $g_{1}$ in virgin silicon samples, we may compare some already known signal. However, we add the possibility of getting averaged $\bar{g}$ 's either by poor local crystallinity of by motional effects. We are thus left with the following possibilities :

- the vacancy-interstitial complex $\left[\mathrm{V}+\mathrm{O}_{\mathrm{i}}\right]^{-}$with $g_{\mathrm{B}_{1}}=2.0050\left(\mathrm{~B}_{1}\right.$ center [4]);

- the unidentified defect occurring as well in crystalline [5] or amorphous [6] silicon, with the isotropic Landé factor $2.005<g<2.007$.

However the latter center has never been observed in purest silicon by EPR ; consequently, we are left with the $B_{1}$ center. Furthermore, this attribution is in accordance with the observation of a level at $\mathrm{E}_{\mathrm{c}}-0.18 \mathrm{eV}$ by DLTS and also ascribed to the same $\left[V+O_{\mathrm{i}}\right]^{-}$center [2].

The intensity of the CR resonance signal is proportional to the carrier lifetimes, therefore to the inverse of the concentration of recombination centers. Thus it is deduced that the latter increase after the regrowth of the layer.

The CR linewidth is proportional to the inverse of the mean collision time of carriers and therefore to the scattering centers concentration. The fact that the electron CR linewidth increases indicates that the negatively charged centers concentration, as for example the $\left[V+O_{\mathrm{i}}\right]^{-}$complexes, increase after the laser shots.

These results clearly indicate the need of operating in vacuum for using these techniques during semiconductor processing.

The $g_{2}$ center in the $P$ implanted silicon has a Landé factor close to that of the conduction band, $g_{\mathrm{CB}}=1.99875$ and is obviously due to the P shallow donors [7]. Indeed, supposing that the $10^{14}{ }^{31} \mathrm{P}$ ions are redistributed in the $200 \mathrm{~nm}$ molten layer, their concentration is always more than $10^{18} \mathrm{~cm}^{-3}$, still high enough to induce motional narrowing effects which suppress the $\mathrm{P}^{4+}$ hyperfine splitting. After the anneal, most of these donors become EPR inactive, possibly by heterogeneous segregation.

Conclusion. - Investigation of laser annealed silicon samples by EPR and CR yields new information about residual defects both in regrowth of virgin silicon and of damaged implanted layers.

Agreement is found between EPR results, leading to the identification of the $\left[V+O_{i}\right]^{-}$complex, in virgin silicon and $\mathrm{CR}$ data.

In phosphorus-implanted silicon, the laser annealing strongly quenches the donor signal. 


\section{References}

[1] GibBons, J. F., Proc. of the laser effects ion implanted. Semiconductors, Catania 1978 (Editor E. Rimini) p. 103.

[2] Benton, J. L., Kimerling, L. C., Miller, G. L., Robinson, D. A. H. and Celler, G. K., Proc. Catania 1978, p. 543. Johnson, N. M., Gold, R. B., Lietola, A. and Gibbons, J. F., Proc. of laser solid interaction and laser processing symposium 28.11-1.12. A.I.P. Conf. Proc. (Edited by Ferris S. D., Leamy J. H. and Poate J. M., Boston, U.S.A.) 1978, p. 550.
[3] Muller, J. C., Scharager, C., Toulemonde, M. and Siffert, P., Rev. Phys. Appl. 14 (1979).

[4] Corbett, J. W., Electron Radiation Damage in Semiconductors and Metals, Solid State Phys. Suppl. 7 (Academic Press, N.Y.) 1966, p. 60.

[5] LePine, D., Phys. Rev. B 6 (1972) 436.

[6] Solomon, I., Biegelsen, D. and Knights, J. C., Solid State Commun. 22 (1977) 505.

[7] YafeT, Y., Solid State Phys. 4 (1963) 50. 